\title{
VIDEO AND AUDIO CONTENT ARE EFFECTIVE COMPONENTS OF SOCIAL NETWORK DEVELOPMENT
}

\begin{abstract}
The questions of the necessity to develop a social network are considered. The developed social network is offered for publishing new posts, adding and removing other members from the friends list, personal correspondence with any member. Particular attention is paid to the issues of using video content and the reasons for the popularity of video content are determined. A simple and user-friendly design is proposed to accomplish the task. The functions of the user in the developed system are considered and the use cases diagram is constructed. The social network database is described. The choice of the PHP programming language for the task implementation is analyzed and substantiated. Features of use and advantages of Open Server and Bootstrap framework are considered. The use in the development of the social network Ajax - the technology of developing web-applications has been substantiated. The work of the developed social network on the part of the user and the administrator are described. Particular attention is paid to the authorization of the user on the network, for the safety of pages. The test results are presented to check the system's correctness and the compliance of its implementation with the requirements. The project has been uploaded to shared hosting, which makes the social network ready for use on the Internet.
\end{abstract}

Keywords: social network, video content, framework.

\section{Introduction}

A social network is a network where people form their social relationships. The main advantage of social media is that almost everyone feels safe and comfortable. It's much easier to make acquaintances this way. Each person feels equal in communicating with the other, it can solve the poor self-esteem problem.

Sometimes people gather around common interests and create a society. This can be a guarantee of development for certain individuals. Programmers can find people who will prompt and help if they have any problems. Artists can find inspiration for new art creations. Others use networks for learning or even work.

Accordingly, the answer to the question of why social networks are so popular in the modern world is the simple fact that they have become an integral part of modern people's lives. More than 4 billion Internet users use social networks, but every day this number is growing and does not plan to stop $[1,2]$.

Social media can take on different trends. For example, Facebook and similar platforms are mainly focused on exchanging photos, information, and statuses between friends. There are also social networks in the form of blogs, such as Twitter or Tumblr. Some networks have a primary goal of forcing groups or communities, and some highlight and reflect only content that is intended for a specific user. The user uses Facebook Messenger, WhatsApp, and other instant messengers if he wants to communicate. YouTube, for example, is needed when a person wants to watch a video of his favorite blogger. And this can happen any day, in any part of the world, but the information you need will always be available. There are also social networks for searching not only people who have certain interests but also the objects of these interests themselves: music, video sites, etc. [3-7].

\section{The main material}

During creating a social network, attention was paid to the video content using. The reasons for the popularity of video content were identified. The success of the video has been confirmed by more than one study [8]:

$80 \%$ of users will choose a live video of a brand instead of reading a post (according to a Livestream survey);

- Video is the content with the highest ROI (according to half of the world's marketers);

- $\quad 76 \%$ of customers bought something only after watching a video with a full description of the product (data from Wyzowl).

Video catches, add color, "revives" the company, brand, product. Mostly millennials (18 to 33) view video content on social media. This is a huge pool of potential customers. Video is about high engagement, which is better than just reaching. Almost half of the users buy something by watching a video on social media networks, and social media algorithms give preference to publications with video.

In the future, the video will grow even more, especially for live broadcasts. Perhaps this will be the main way to attract an audience. Now, when even an ordinary pupil with gadgets aid and applications is able to create "authentic" photos, and live broadcasts are becoming real salvation. Technically, they are the hardest to fake, but there are many ways to prove that everything is happening "right now". And most importantly: it is inexpensive. Even ordinary people, not just entrepreneurs, can create such content without much investment of time and money.

During creating a social network for watching video content, you need to remember:

- The first 10 seconds are decisive.

- Naturalness.

- The video should make you want to share.

- The main thing is not views, but contact.

- "No" - venality, "Yes" - interesting content.

- Humor and originality

- Brevity.

The design for a social network should be simple and straightforward for the user. All pages should have a similar theme and not differ in style. Using the Figma 
system, we will develop layouts of software modules and present the main ones (Fig. 2).

\section{Biological}

-Viewing saves time that is usually spent processing letters. The speed of image perception is 60 thousand times faster than the speed of text perception. This is how the human brain works.

\section{Emotional}

-With the help of a video series, you can convey much more information, impressions than a single text or just sound.

\section{Logical}

-Today, video is the content that is the hardest to fake. It is almost impossible for an amateur to turn this around, and the format of live broadcasts gives an additional incentive to trust the eyes.

\section{Social}

-The speed of life, the speed of information exchange is now very high. Instead of looking at photos, linking them to a list of features and analyzing reviews and individual blocks on the sales page, it's much easier and faster to see a comprehensive product overview.

Fig. 1. Video content popularity reasons

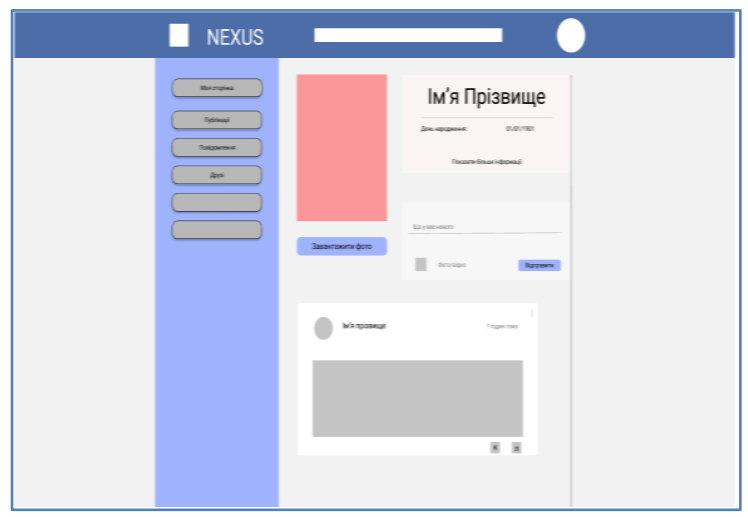

Fig. 2. User profile page layout

All pages of the system have a common color scheme, which allows the user to switch between pages without discomfort in the visual perception of information.

For a more specific understanding of the user's functions in the system being developed, it is necessary to build a use case diagram.

A use case diagram depicts the interaction between characters (users) and precedents (use cases) and describes the logic of the system. It allows formulating all the functions that the system supports and for which users they will be available [9].

A character (actor) is any user of the system that does not play a role in relation to it.

In this system, an actor can only be an authorized member of a social network. A person can do the following: add and edit information about yourself; view all system users and their profiles; add and remove other members from the list of friends; add new publications where you can describe interesting information; view your friends' posts; write comments for any publications; write messages to other participants in a personal chat.

The system's use case diagram is shown in Fig. 3. The character is the user of the system.

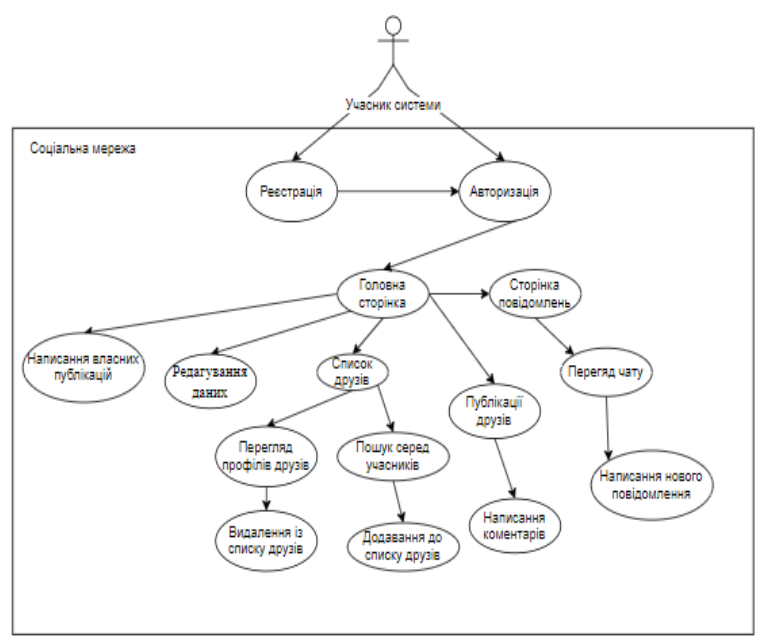

Fig. 3. The use case social network diagram

As you can see in Fig. 3, the entire range of system capabilities becomes available to the participant only after authorization.

A database is an ordered collection of data that share common properties and are designed to meet user needs. Typically, they are used for dynamic sites with a lot of data [10].

A database management system (DBMS) is a complex of software and language tools used to create and maintain the functioning of databases. They also allow you to search and modify.

The main reason for the popularity of databases is their usability. The syntax of the most popular DBMS is as clear as possible and uses the words we know, so every query can be read without any problems. It is also easy to change the data because the information in the rows can be interrelated and changing one will lead to a change in all others that use it.

A relational database is a database built based on a relational model, it stores information in spreadsheets, and data retrieval from one table is done using a relationship defined in another table.

Thus, the relational database supports what is called the entity-relationship model. The main advantage of this model is simplicity and ease of understanding for the user. And the only constituent structure of this system is the table.

It can also be noted that other data models can occur from the entity-relationship model, therefore it is the most general.

Let's describe the social network database. It consists of the following tables:

a) user (it stores all user data):

- id (user id); 
- firstname (username);

- last name (username);

- birthday (date of birth of the user);

- phone (user's phone);

- address (user address);

- photo (personal photo of the user); data):

b) authorization (table for storing authorization

- id (line id);

- email (e-mail);

- password (user password);

- confirm_mail (code that is sent to the user's mail for confirmation);

- verified (message or user confirmed mail)

c) friends:

- id (line id);

- user_id (id of the user who made the request);

- friend_id (id of the requested user);

- status (status of relationships between users);

d) messages (message table):

- id (message id);

- sender_id (sender id);

- receiver_id (recipient id);

- message_text;

- message_time (time of sending);

e) post (publication table):

- id_post (publication id);

- author_id (author id);

- content (text of the publication);

- img (photo of the publication);

- likes (array of users who liked the post);

- comments (array of comments for publication);

- time (time of publication).

To implement the set task, the programming language PHP was chosen.

Reasons for choosing a programming language:

1. Simple and convenient syntax. PHP can be used even by beginners who can build small programs. And PHP code is easy to read and modify.

2. The popularity of the language. More than $75 \%$ of sites are written in PHP. In this percentage, the largest contribution was made by CMS systems, especially WordPress. Also quite popular are Joomla and Drupal which are also written in PHP [11].

3. Detailed documentation. On the official PHP site, you can find information about each component of the language, examples, and terms of use, which makes the use as convenient as possible.

4. Embedded in HTML documents. PHP code blocks can be added to any part of an HTML document, as well as to any part of a tag or its attributes. And it doesn't break the structure of the document.

5. All PHP code is executed on the server. The client can only see the result as an HTML document. And site pages are dynamically created and quickly generated.

We used Bootstrap - the most popular HTML, CSS, and JS framework that is used for project development. There are ready-made scripts and styles inside the user's Bootstrap. And to use them, you just need to add classes and HTML attributes to them [12]. The framework helps developers develop websites more easily. If you develop a system from scratch, then all CSS styles will have to be written from scratch, and this may be more than one hundred pages of code. In addition, various errors constantly appear during development, the solution of which delays the development.

The responsive version of the site using Bootstrap is much easier to create than without it since all the elements are pre-styled.

Also, the system complex package OPEN SERVER was used as a web server. Open Server is a portable local WAMP / WNMP server that has a feature-rich manager program and a wide variety of components. The main advantage of this software package is those functions that are created specifically for users, taking into account their recommendations and wishes.

Open Server is a completely portable server that does not have any system services. You can download it to a USB flash drive and run it on any machine without fear that something will not work.

Features of Open Server:

a) detailed viewing of the logs of all components in real-time;

b) choice of HTTP, DBMS, and PHP modules in any combination;

c) support for domain pointers, as well as a convenient form of their configuration;

d) creating a local subdomain without losing the visibility of the main domain on the Internet;

e) quick access to domains and module configuration templates;

f) multilingual interface (Russian, Ukrainian, English).

MySQL was chosen as the database server - the most popular system was created for database management. This relational system uses all known subsystems, namely: InnoDB, MyISAM, Archive, and others. MySQL is a great solution for small applications. On Unix servers, the possibilities are maximized, because they have support for a lot of threading, which increases the performance gain.

MySQL supports the SQL query language in many extensions of the ANSI 92 standard, which various DBMS cannot offer. It is also popular for its speed and reliability. MySQL advantages:

a) performance;

b) ease of use;

c) free use with no fee.

At the developing social network stage, it becomes necessary to use Ajax technology. Ajax is a web application development technology that uses code on a client machine to modify data on a web server. As a result, web pages are dynamically refreshed without reloading a full-page, interrupting data exchange. When using $\mathrm{AJAX}$, there is no need to update the entire page every time, because only a specific part of it is updated, which makes using the system much more convenient [13]. The use of Ajax is done using Javascript, namely the XMLHttpRequest object. It allows the client to make HTTP requests (GET or POST) and parses the response. 
Then the HTTP request goes to the address specified in the URL to the file that will carry out the calculation. Usually, this is a PHP file that interacts with the database and sends a response which is stored in XMLHttpRequest. This answer is analyzed and displayed in the appropriate block instantly.

The stylistic design of the social network is based on the interaction of white and blue colors of various shades.

As a result of the software module's development, the final product corresponds to the developed layouts (Fig. 4 - 7).

First of all, the user goes to the authorization page and is obliged to $\log$ in to use all the functions of the system. If he independently tries to go to any page, the system will automatically return him to authorization. During entering, you need to specify your mail and password.

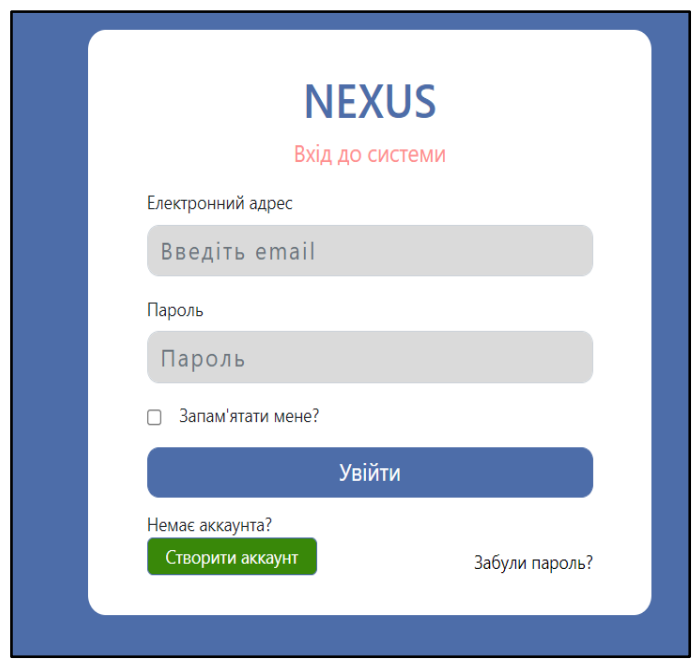

Fig. 4. Authorization window

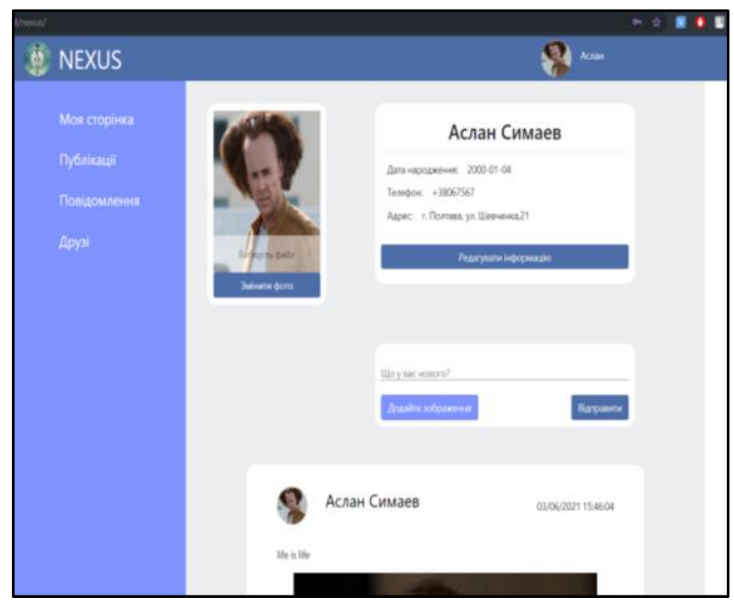

Fig. 5. User home page

If the user does not have an account, he can register. After logging in to the account, the user gets to his page.

After authorization, the user gets the opportunity to use all the features of the system. The user has the ability to edit personal information.
After selecting a chat, you can go to the personal correspondence of the participants.

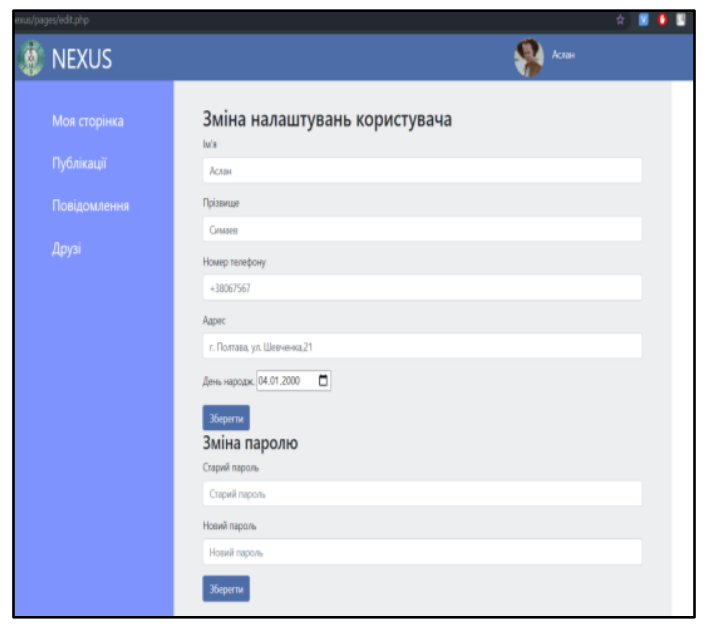

Fig. 6. Change user settings

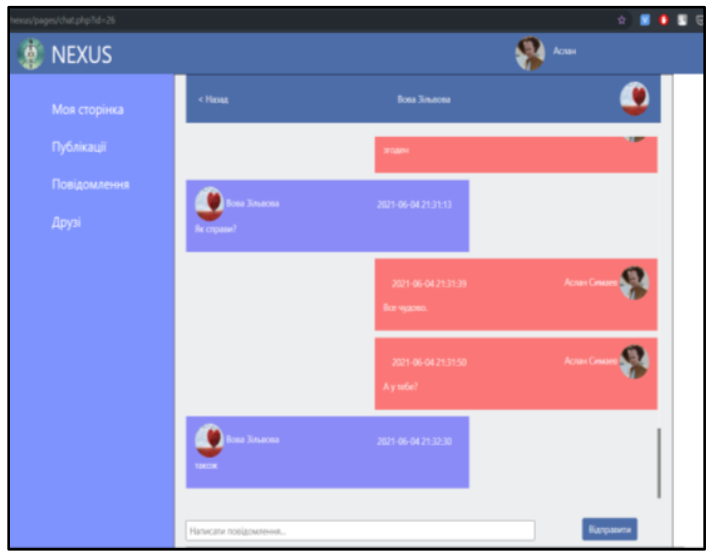

Fig. 7. Personal correspondence page

You can see a list of your friends on the friends page. Clicking the "Find Friends" button opens a modal window showing all users of the system.

You can also note that this window implements a dynamic search and by entering only one letter, you can already reduce the number of displayed users.

By selecting one of the users, you can go to the personal page, where you can view posts or change the relationship with this user.

To verify the correct operation of the system and compliance of its implementation with the requirements, testing was performed, which consisted of three parts [14]:

a) regression testing;

b) functional testing;

c) user interface testing.

As a result of the previous stages of work, a serviceable system was developed, which is ready for commissioning. For that, you need to upload the finished project from the local server to the hosting.

Hosting is a service that allows you to host a website on the Internet. It is saved and a suitable server for it. Moreover, this site will be freely available at any time, any day, while this hosting is active. 
To upload the site to the server, Fornex virtual hosting was used [15].

This hosting has quite reasonable prices, and at the same time has a user-friendly interface and detailed system statistics.

After registering and creating a new domain, you can start uploading project files to the server. This procedure was done using the Filezilla app.

\section{Conclusions}

The work has developed a social network that performs the main functions of the most popular social networks, namely: publishing new posts, adding and removing other participants from the friends list, personal correspondence with any participant.

Particular attention is paid to the location of the video feed on the social network.
In the process of creating the project, the reasons for the success of this system type were considered. Using the example of the three most popular representatives, the main secrets that made social networks popular were considered.

Thanks to the analysis carried out, network layouts were developed that make the interface the most userfriendly and have all the necessary windows in the most convenient access. Also, the developed database has all the necessary fields for the functioning of the system.

During the development of the software product, modern web technologies were selected and justified, allowing the creation of interactive web pages.

With the help of modern resources, the project was uploaded to virtual hosting, which makes the social network ready for use on the Internet.

\section{REFERENCES}

1. Маркетер [Електронний ресурс] - Режим доступу до ресурсу: https://marketer.ua/ua/the-most-popular-social-networksin-the-world//(accessed July 15, 2020).

2. Igroup. Соціальні мережі [Електронний ресурс] - режим доступу до ресурсу: https://igroup.com.ua/seoarticles/sotsialna-merezha/(accessed May 25, 2021).

3. Патюков, С.В. Социальная сеть: понятие, история возникновения, современное положение дел / С.В. Патюков, Е.В. Коврига. - Текст : непосредственный // Юный ученый. — 2017. - № 2 (11). — C. 75-77. — URL: https://moluch.ru/young/archive/11/873/ (дата обращения: 16.02.2021).

4. Iklife [Електронний ресурс] - режим доступу до ресурсу: https://iklife.ru/socialnye-seti/instagram/chto-takoe-instagrami-zachem-on-nuzhen.html.

5. Igroup [Електронний ресурс] - режим доступу до ресурсу: https://igroup.com.ua/seo-articles/facebook/.

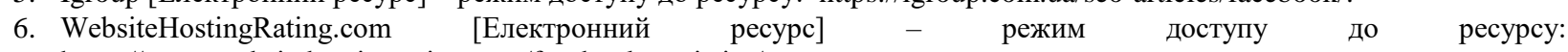
https://www.websitehostingrating.com/facebook-statistics/.

7. Soeded [Електронний ресурс] - режим доступу до ресурсу: http://www.seoded.ru/istoriya/internet-history/istoriyavkontakte.html.

8. Gallardo D. (2020). Easy navigation for your videos with Chapters. Vimeo blog. / [Electronic resource] - Access mode: URL: https://vimeo.com/blog/post/easy-navigation-for-your-videos-with-chapte

9. Основи UML [Електронний ресурс] - режим доступу до ресурсу: https://prog-cpp.ru/uml-classes/

10. APEPS. Що таке база даних? [Електронний ресурс] - режим доступу до ресурсу: http://apeps.kpi.ua/shco-take-basadanykh

11. Рідний Дім [Електронний ресурс] - режим доступу до ресурсу: http://ridnuydim.narod.ru/

12. Webformyself. Що таке Bootstrap [Електронний ресурс] - режим доступу до pecypcy: https://webformyself.com/chtotakoe-bootstrap/

13. Технологія AJAX [Електронний ресурс] // ACOI. - 2016. - Режим доступу до ресурсу: http://ua-referat.comAJAX.

14. LibMDPU. Тестування програмного продукту [Електронний ресурс] - режим доступу до ресурсу: http://lib.mdpu.org.ua/e-book/vstup/L11.html.

15. Fornex [Електронний ресурс] - режим доступу до ресурсу: https://fornex.com/.

Received (Надійшла) 22.06.2021

Accepted for publication (Прийнята до друку) 11.08.2021

\section{Відео та аудіо контент - ефективні складові розробки соціальної мережі}

\section{А. С. Сімаєв, Т. М. Деркач, Т. А. Дмитренко}

Анотація. Розглянуто питання необхідності розробки соціальної мережі. Запропонована розроблена соціальна мережа для публікацій нових постів, додавання та видалення з списку друзів інших учасників, персональна переписка 3 будь-яким учасником. Особлива увага приділена питанням використання відеоконтента та визначені причини популярності видеоконтента. Для реалізації поставленої задачі запропоновано простий та зрозумілий для користувача дизайн. Розглянуті функції користувача у системи яка розробляється, для чого побудована діаграма прецедентів. Описана база даних соціальної мережі. Проаналізовано та обгрунтовано вибір мови програмування РНР, для реалізації поставленої задачі. Розглянуто особливості використання та переваги Open Server та фреймворка Bootstrap. Обгрунтовано використання при розробці соціальної мережі Ајах технології - технології розробки web-додатків. Описано роботу розробленої соціальної мережі зі сторони користувача та адміністратора. Особлива увага приділяється авторизації користувача в мережі, для безпеки сторінок. Надано результати тестування, для перевірки правильності роботи системи та відповідності їі реалізації до вимог. Проведено завантаження проекту на віртуальний хостинг, що робить соціальну мережу готовою для використання в інтернеті.

Кл ючов і сл ов а : соціальна мережа, відеоконтент, фреймворк. 